\title{
A Vision of the Planet of the Earth in the Next 300 - 500 Years under Climate Change with Proposed Measures to Mitigate the Effects of Climate Change
}

\author{
Severin Šikanja \\ Metropolitan University-Belgrade, Faculty of Applied Ecology, Belgrade, Serbia \\ Email: sevke@yahoo.com
}

How to cite this paper: Šikanja, S. (2020). A Vision of the Planet of the Earth in the Next 300 - 500 Years under Climate Change with Proposed Measures to Mitigate the Effects of Climate Change. Open Journal of Forestry, 10, 155-171.

https://doi.org/10.4236/ojf.2020.101011

Received: December 11, 2019

Accepted: January 16, 2020

Published: January 19, 2020

\section{Copyright $\odot 2020$ by author(s) and} Scientific Research Publishing Inc. This work is licensed under the Creative Commons Attribution International License (CC BY 4.0).

http://creativecommons.org/licenses/by/4.0/

\begin{abstract}
The paper will present climate change, (global warming), and what is most important, the lasting consequences for planet Earth, which will be reflected for 500 years and maybe even before that deadline, the greatest environmental catastrophe that has not hit planet Earth since its inception will be felt. This will actually be the end of life on planet Earth and for the modern man (Homo sapiens Lat.). Measures that will be proposed in the work, as possible mitigation of the consequences of catastrophic consequences on planet Earth and life on it, in fact, they can only prolong or slightly reduce the end of life on planet earth that is imminent. The Titanic people only had 2.5 hours to live. "WE WILL HAVE A 500 YEARS".
\end{abstract}

\section{Keywords}

Planet Earth, Ecological, Climate Change, The End

\section{Introduction}

Our planet has been facing a great deal of catastrophic climate change in recent years and decades. Since the creation of planet Earth, climate change has often been the result of natural circumstances such as increased activity on the sun, large-scale volcanic eruptions, and more. The great growth of the human population and the intense industrial development (the era of the Industrial Revolution) make the anthropogenic factor become the main and largest "driver" of climate change. The consequences of climate change can seriously affect the development and survival of human civilization (Barnett, Adam, \& Lettenmaier, 
2005). All these changes also lead to major environmental problems, such as the extinction of many animal and plant species, the occurrence of acid rain and many others. Climate change is a global phenomenon and no country will be spared, but the consequences will not be shared equally. Living in these conditions will be significantly different from what we are used to, which will require a large number of activities aimed at maintaining a certain level of quality of life (Biondi \& Waikul, 2002). For thousands of years, nature has helped man survive, and man has used natural wealth ruthlessly. The balance of man and nature has existed for centuries.

In our recent history, owing to the great advances in science and technology, man through his activity leads to environmental damage to the extent that threatens to endanger his survival (Williams et al., 2013). During its activities such as urbanization or exploitation, man changes his environment by damaging the natural environment. The construction of hydroelectric power plants and reservoirs, logging, overexploitation of mineral resources, landfill creation, uncontrolled gas emission, continuous nuclear testing and similar activities, affect the change of entire areas and landscapes (atmosphere, climate change, rising sea levels and disrupting the ozone layer). It is the major trigger for any negative changes in climate and environment (Briffa et al., 2002).

From the moment when a person begins to think about his environment, to preserve and feel his part, and when his conscience begins to grow into ecological ethics and morality, one can speak about environmental protection. Environmental protection means a set of different actions and measures taken to prevent environmental threats and preserve biological balance (Brković, 2015). The fact is that the climate has changed a lot in recent years, and can be said for a decade. The effects of climate disruption are clearly reflected in rising temperatures, the disappearance of some plant animal species, increasingly severe droughts, and frequent flooding, both worldwide and in our country (Ault \& George, 2010).

Forests, as an important natural resource, are a major factor in the stability of climate elements and phenomena, and thus have a major impact on the stability of all ecosystems. In addition to the significant climate change that threatens to endanger humanity, forests are of great importance in the generation of oxygen, the purification of air from dust and other particulates that enter the atmosphere. They also regulate the amount and distribution of rainfall, affect the quality of water on Earth, prevent floods, erosion and landslides, improve soil nutrition and increase its fertility. They are the guardians of biodiversity and gene pool, whose survival depends on many species of plants, fungi and animals (http://www.interboreal.org/).

In addition to the significant role of forests in maintaining climate balance, as well as the very survival of man and planet Earth, forests are disappearing at an incredible speed on our planet. People are cutting down forests for the growing need for habitat, for conversion to agricultural land, for roads and for various other uses. World forest areas are significantly reduced each year. Every year, 
tens of thousands of hectares of forest are cut down in the world. These will be felt by our generations. The disappearance of forests continues due to climate change despite global efforts to reduce greenhouse gas emissions into the atmosphere (http://www.fao.org/home/en/). At the turn of the 20th to the 21 st century, human civilization has produced a wealth of evidence for the global crisis and is increasingly being written about forests and climate as indispensable factors for survival on planet Earth-The Apocalypse Has Begun.

With this sentence, the world media begins with articles covering an article by Nature, one of the most recognized scientific journals on climate change. This is a study by the University of Hawaii where reference laboratories are located to measure $\mathrm{CO}_{2}$ concentrations in the atmosphere (https://www.nature.com/). Combustion of fossil fuels releases carbon dioxide into the atmosphere, contributing to an increase in its concentration in the atmosphere and, as a consequence, global warming and climate change. Trees and forests mitigate these changes by removing carbon dioxide from the air and converting it with photosynthesis into carbon, which they then store in a process called carbon capture. While the atmosphere contains about 750 billion tonnes of carbon in the form of carbon dioxide, forests contain about 2000 billion tonnes of carbon. Approximately 500 billion tonnes of carbon have been accumulated in trees and shrubs and 1500 billion tonnes in peatlands, soils and forest areas. Of that amount, about 100 billion tonnes circulate through the atmosphere each year. Even small changes in the rate of photosynthesis, decay, and respiration can cause major changes in $\mathrm{CO}_{2}$ levels and, consequently, in global climate (Wilson, Luckman, \& Esper, 2005), in a few decades.

According to theory, carbon dioxide can improve plant growth and development, so forests can grow faster due to increased $\mathrm{CO}_{2}$ levels in the atmosphere. Experiments in laboratory conditions have shown that a twofold increase in carbon dioxide levels leads to an initial increase in growth from $20 \%$ to $120 \%$ with an average increase of $40 \%$ (Eamus \& Jarvis, 1989). In some cases, an increase in carbon dioxide levels only temporarily aids growth, and with a further increase in $\mathrm{CO}_{2}$ concentration can even reduce it. The decrease in growth can be caused by an increase in starch in the leaves and a reduction in photosynthesis (Wullschleger et al., 1990). Increased temperatures theoretically increase the rate of all chemical and biochemical processes in plants and soil. The temperature dependence of the diffusion in the liquid phase and the mass flow led by osmotic pressure is similar to that of metabolic processes (Sano, Furuta, \& Sweda, 2009).

The climate on Earth was slowly and gradually changing. Formerly, until the beginning of the Industrial Revolution, the climate was changing as a result of changing natural circumstances. Today, the term climate change is used to refer to climate change, which has been going on since the beginning of the twentieth century. Changes that were registered in the past, as well as those that are predicted for the next 80 years, are considered as occurrences resulting from human activities and not as a result of natural changes in the atmosphere 
(http://www.climatechange.org/). According to (Daly et al., 2008), climate change would change the mean annual global temperature of the atmosphere, which would increase by $1.6^{\circ} \mathrm{C}$ to $6.4^{\circ} \mathrm{C}$ by 2100 . Warming the Earth's atmosphere will lead to a number of serious environmental changes, such as extreme droughts, floods, cataclysmic fires, greater frequency and severity of storms, hurricanes, in the coming decades and centuries, there will be an increasing number of earthquakes, volcanoes, glaciers and polar ice causing sea level rise and frequent water spills in densely populated areas.

\section{Methodology of Work}

\section{IMPORTANT:}

This scientific work is the result of many years of analysis and study of the characteristics of the planet earth, as well as a detailed look at the effects of climate change. The consequences of climate change-shown in Scheme 1 and Scheme 2-will be incomprehensible and catastrophe for humans and for planet Earth in particular, and the environment if nothing is immediately done, but I think it's too late.

Research scheme:

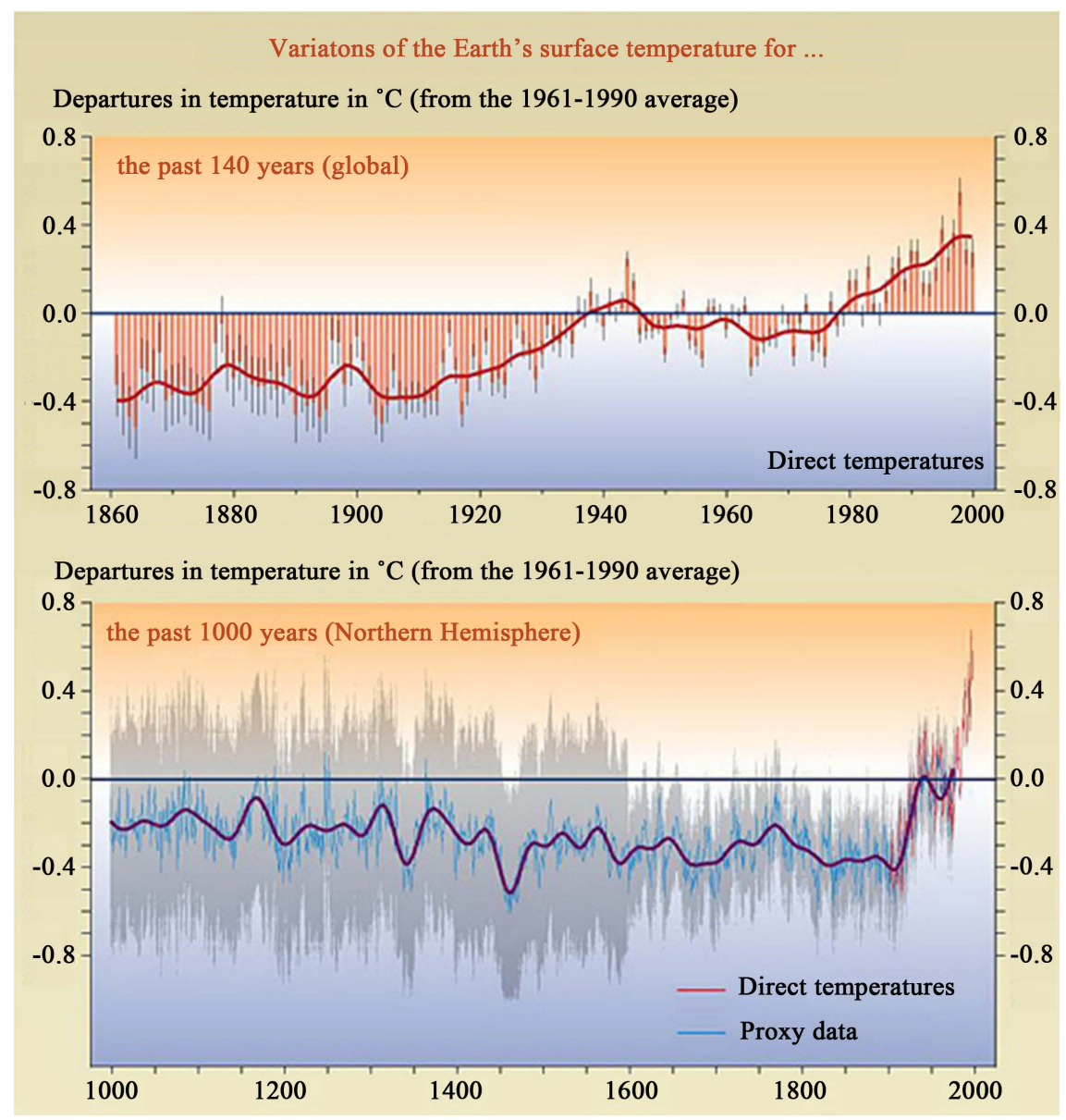

Scheme 1. Sematic representation of global temperature rise. 


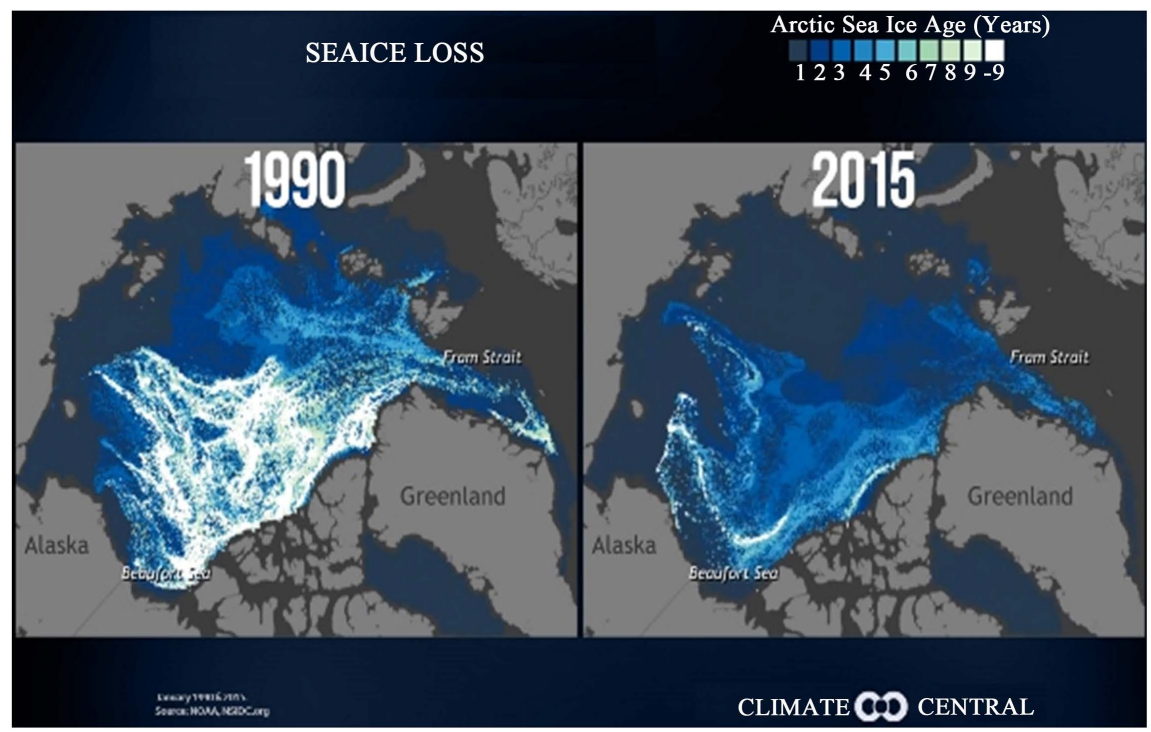

Scheme 2. Sematic representation of melting ice at the poles (Source: for Scheme 1 and Scheme 2-IPCC International Panel on Climate Change).

Based on the charts presented, provided by the official NASA, IPCC, NOAA official institutions, it is clear that planet Earth is in increasing danger every day, and that the irreversible consequences (listed in points 1 - 10 in this paper) will happen if does nothing right now.

\subsection{Forest State in the World}

\section{WARNING:}

What is happening this summer with the forests in Siberia, this year-2019where 4 million hectares of forests are burning, this is more than a warning, will we have enough oxygen at all to breathe. Furthermore, nothing after these fires in Siberia will ever be the same on planet Earth. Mountains in southern Europe, Greece, Amazon region-Brazil, 4 million hectares of forests in the world are disappearing, life on planet Earth will disappear. When there will be new afforestation, how long will it take for this huge ecosystem to regenerate. Few of our lives are left on planet Earth.

Forests cover an area of $4.1 \times 10^{9}$ ha on Earth. Forests that represent a significant carbon reservoir have been identified as an important potential to mitigate global warming through their capacity to bind and accumulate carbon

(http://www.fao.org/home/en/). As national treasure of every country and as an important natural resource, they have an immeasurable ecological and economic importance, because forests have always responded to the socio-economic needs of society. If, in addition to all the functions of forests as a traditional source of energy, raw materials, healthy food, water, we also take into account man's relationship to the forest and the environment pollution, forest and forest land degradation, humankind must seriously wonder what the future holds for us. Forests are massively deforested and are being cut down on hundreds of thousands of hectares worldwide to build roads, facilities and bring them to another pur- 
pose (Grabner, 2005). Deforestation further contributes to the acceleration of climate change. Regardless of the size of a country, the future of each climate depends largely on the type of forest and the area under forest cover. Reduction in forest cover causes a decrease in air quality, which further affects the poor health of the population and increases the risk of disease (Loomis, Koteen, \& Hurd, 2003).

Data show that there has been a significant deforestation in the last 20 years, and this has been due to increased demand for land used for agriculture or residential construction. Forests are also being cut due to increased paper and heating needs. Since 1990, the problem of declining forest cover has been the greatest in developing countries that are constantly exploiting their natural resources-such as Indonesia, Guatemala and others. In these countries, it is characteristic that they cannot afford the cost of afforestation, so that there is no new planting after deforestation. Wealthier countries, such as Switzerland, Canada, and Sweden, have managed to retain forested areas and some have expanded forest areas. Globally, the trend is clear, i.e. forests are disappearing rapidly. It is important to emphasize that forests are a powerful global climate modifier, with a particularly large impact on their immediate environment, and a very important factor for the living conditions of other ecosystems (Meffe, 2000).

Natural disasters only exacerbate the situation, and their numbers are also increasing as a result of climate change. When we look and compare what some areas of the planet looked like just 100 or 200 years ago, and what they look like today, the conclusion is obvious.

According to the United Nations Food and Agriculture Organization forested areas continue to decline everywhere in the world, especially in South America and Africa. "Better awareness of forest resources is fundamental to preventing illegal logging and forest degradation", it said (http://www.fao.org/home/en/). Table 1 shows the 10 countries in the world that have the largest areas under forests.

The most recent data show that in the last 20 years the world's forest area has decreased by four times the area of Italy. According to experts, between 1990 and 2010, some 5.3 million hectares of forest worldwide have disappeared annually. The results of a global survey show that in 2010 (Figure 1) the total forest area was 3.89 billion hectares, which is $30 \%$ of the land. The forest used to cover almost two-thirds of the land, but to date, much of that wealth has been destroyed, mostly by excessive logging to create space for new settlements, agricultural land, factories and roads, as well as for the timber industry. Deforestation has serious environmental consequences (Figure 2) - an obvious example of the destruction and deforestation in Indonesia (according to the scale of the figure it can be concluded which area is involved). The consequences are a decrease in biodiversity, the disappearance of certain plant and animal species, and climate change.

Forests are also important because only one tree releases as much as 250 meters of cubic oxygen in a year, which is enough for the needs of two adults. How 


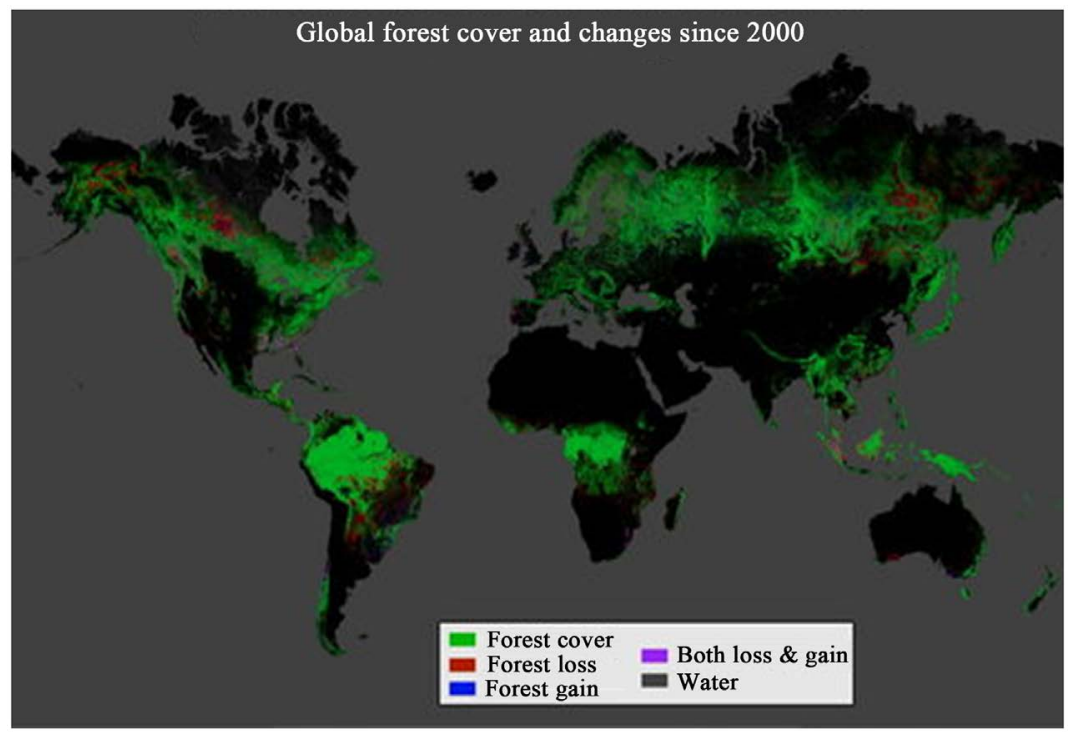

Figure 1. State of the world forests (Source: Meffe, 2000).

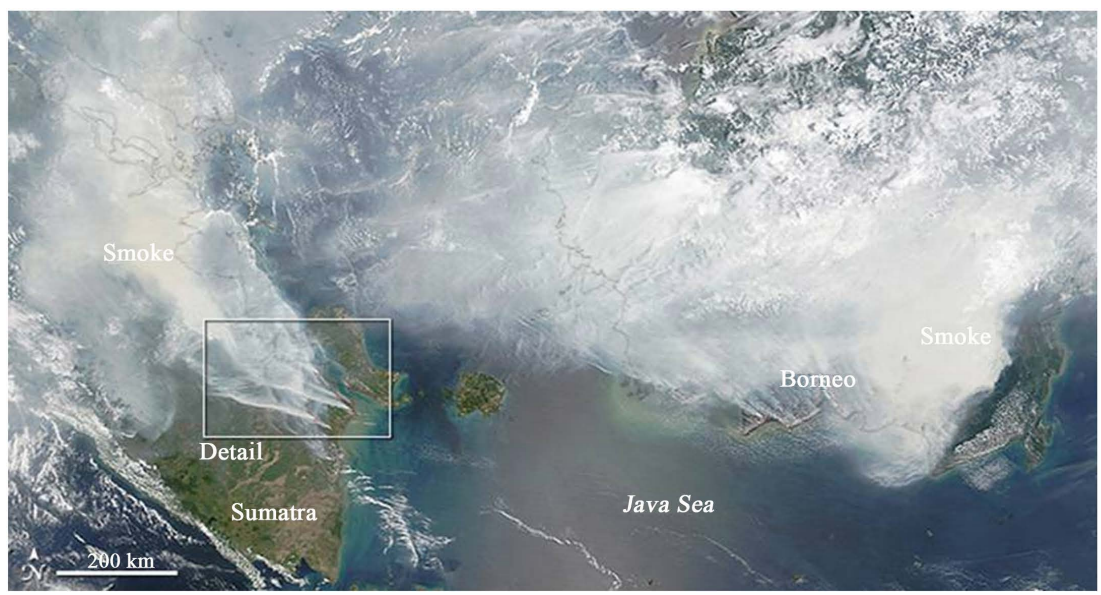

Figure 2. Satellite image of smoke resulting from deforestation in Sumatra and Borneo (Indonesia). Source: The framed area is $5000 \mathrm{~km}^{2}$.

Table 1. According to data of the first ten countries with the richest forests on the planet: State Measure: in thousands of acres (000 ha).

\begin{tabular}{ccc}
\hline & Russia & 808,790 ha \\
2 & Brasil & 477,698 ha \\
4 & Canada & 310,134 ha \\
5 & USA & 303,089 ha \\
6 & China & 197,290 ha \\
7 & Australia & 163,678 ha \\
8 & Dem. Tail. Congo & 133,610 ha \\
9 & Indonesia & 88,495 ha \\
10 & Peru & 68,495 ha
\end{tabular}

(Source: Meffe, 2000). 
important forests are to humanity is the following data: 10 ha of high-cultivatedmature forests absorb almost 100 tonnes of carbon dioxide a year. 10 ha of non-cultivated forest (left to the elements) absorbs about 9 - 10 tonnes of $\mathrm{CO}_{2}$ per year, which is ten times less (from this we can see how important it is for proper forest management and cultivation), and 10 ha of bare land with no trees and vegetation absorbs about 1 ton of $\mathrm{CO}_{2}$ annually (Fritts, 1974). From this, one can clearly see the importance of forests for humanity.

Based on the picture, it can be concluded that these are large expanses. Unfortunately, this is not the only area in the world where deforestation is taking place. Forests are mostly deforested to divert land for other purposes: agriculture, construction of various buildings, and housing for an increasing population. There are already seven billion people in the world, and food, water and heating needs have been increasing for decades. If we were to interpolate between 1000 and 2025 on the diagram, it would be seen that the world's population began to grow rapidly in the 18th century, coinciding with the beginning of the industrial revolution. This is important to emphasize because it is precisely this increase in the world's population that has caused all the negative consequences for planet Earth and the environment, the destruction of forests and more.

\subsection{Climate Change in the World}

No other scientific discipline undergoes as rigorous a UN-controlled scientific assessment process as climate and climate change (Funk, Hoell, \& Stone, 2014). Compared to a period of 150 years ago, the average temperature of our planet has increased by $0.5^{\circ} \mathrm{C}$, which was the first hint of recent climate change (Bradley et al., 2000). Since the establishment of the United Nations Intergovernmental Panel on Climate Change in Geneva in November 1988, the climate and climate change assessment system have evolved to a level we did not know before. Working Group-(IPCC-International Panel on Climate Change) 2/2/2007 year, she gave her fourth report. That report most seriously warns that if climate change continues like this, and nothing is done to reduce the "greenhouse effect", the entire world could very quickly face the unprecedented consequences of climate change. Due to climate change, there are still many open questions in climate science. However, the relatively high investment in research funding and research has in some cases provided partial answers (Christian-Smith et al., 2014). The climate has always been gradually changing, but the first major changes could be noticed even after the industrial revolution that took place in the second half of the 18th century.

With the development of industry, science and technology, man began slowly but surely polluting and destroying the environment. The past few decades have witnessed more obvious changes in climate. Previously, the climate changed solely as a result of changes in natural conditions. But with the development of industry and modern technology in all fields, as well as population growth, the 
anthropogenic factor is taking over the primacy (Friedrich et al., 2007). If we look at Figure 3, we will see how much the temperature has changed in the last two centuries, i.e. how warm the planet Earth is (Figure 3), which is very warning.

The rise in temperature on our planet is one of the significant topics that has attracted the attention of climate scientists over the last few decades.

It is believed that the impact of climate change will grow in the near and distant future and that its effects will be largely adverse to life on planet Earth. Climate scientists and those on the subject do not have fully agreed opinions on the causes and consequences of climate change. What is climate change and what is their impact on quality of life? Climate change is likely to increase the frequency and intensity of forest fires, the occurrence of severe storms, insect invasion and other adverse events in the future. Forest productivity and distribution in the future may be affected by changes in temperature (Figure 3)-precipitation and carbon dioxide in the air. Climate change is also likely to bring about problems that forests will face, such as changes in land and air pollution (Loomis et al., 2003).

The greenhouse effect is very important when it comes to climate change. Carbon dioxide with other gases forms a layer around the Earth's surface, partially absorbs the reflected sun's rays from the Earth's surface, and emits thermal radiation, which transforms planet Earth into a huge glass garden. Table 2 just shows that $\mathrm{CO}_{2}$ is the most represented greenhouse gas and thus one of the most important causes of this effect.
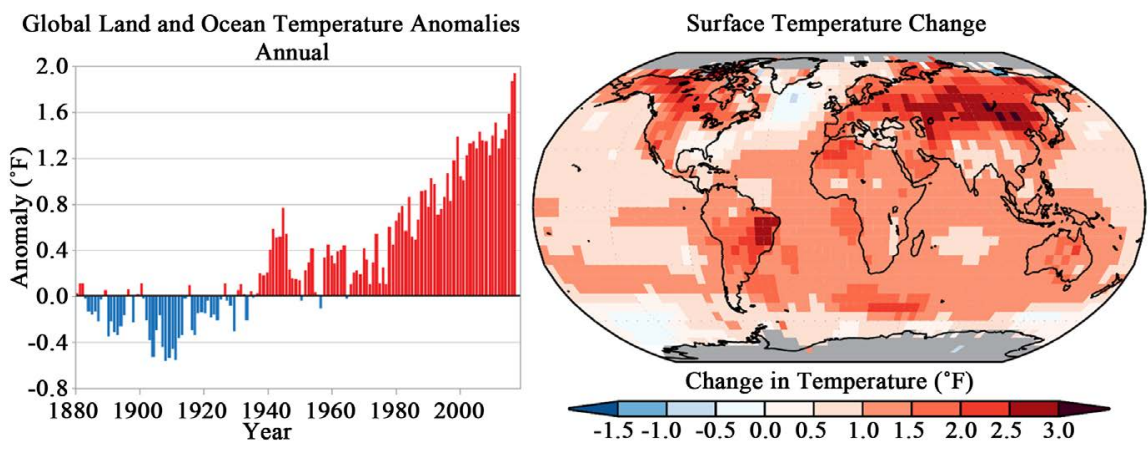

Figure 3. Changing the global temperature on the Earth's surface over the last two centuries (Source: Wilson, Luckman, \& Esper, 2005).

Table 2. Percentage composition of greenhouse gases in Earth's atmosphere.

\begin{tabular}{ccc}
\hline 1 & Carbon dioxide & $62 \%$ \\
2 & Methane $\mathrm{CH}_{4}$ & $13 \%$ \\
3 & Nitrogen oxides $\mathrm{NO}_{2}, \mathrm{NO}_{3}$ & $10 \%$ \\
4 & Freons & $9 \%$ \\
5 & Other & $6 \%$ \\
& Total & $100 \%$ \\
\hline
\end{tabular}

(Source: Barnett, Adam, \& Lettenmaier (2005). Potential impacts of warming. Climate on water availability in snow-dominated regions. Nature 438, 303e309). 
In Figure 4, one can clearly see which countries-regions are "most contributing" to annual $\mathrm{CO}_{2}$ emissions in the world. These are the USA, Russia, the countries of Western Europe, i.e. the countries with the highest economic progress have the highest pollution. Unfortunately, there is a strong correlation that does not support the protection of planet Earth and the environment. On the other hand, we will see which countries in the region are the least involved in $\mathrm{CO}_{2}$ emissions, namely the countries of the African continent, the Middle East, Central and South America. Climate change, through increasing temperatures, has a very negative impact on forests. Forests are more susceptible to various entomological and phytopathological diseases, which eventually leads to drying up and forest degradation (IPCC International Panel on Climate Change). It is estimated that at least a third of the world's forests can be threatened by climate change.

A billion-ton iceberg has begun to separate from the Antarctic (Figure 5). This has never happened before. Perhaps this is the last rebuke to humanity. Climate change is slow and seemingly invisible. However, when noticed, it may be late.

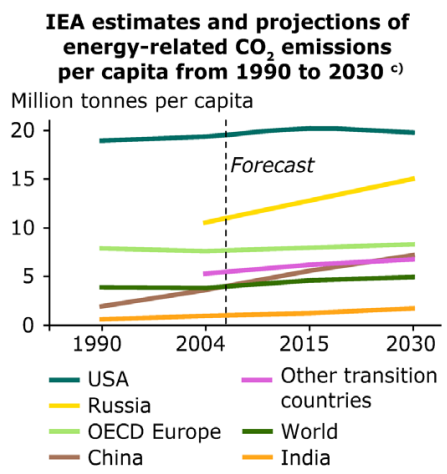

Figure 4. $\mathrm{CO}_{2}$ emissions worldwide (by region in the world) (until 2030). (Source: http://www.eea.europa.eu/ European Environment Agency). Note: This is only a $\mathrm{CO}_{2}$ emission forecast, up to 2030 , if nothing is done.

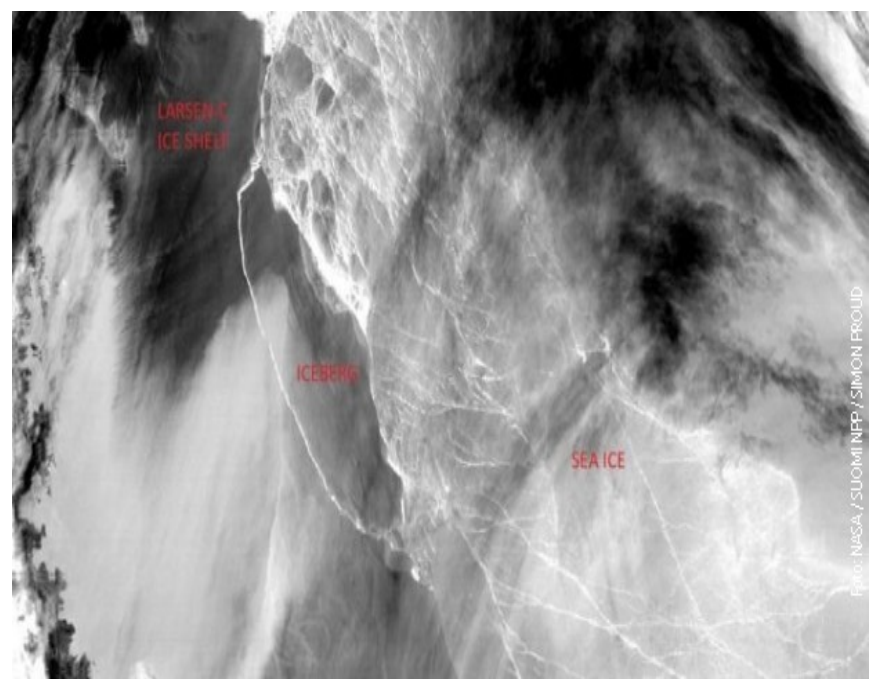

Figure 5. The iceberg (Larsen C) began to separate from the Antarctic surface in 2017. 
The results: (This is very likely to happen if nothing is done urgently at the entire planet Earth)

1) In the next 200 - 250 years, all the ice on planet Earth will melt from all glaciers and from the North and South Poles.

2) Therefore, all coastal cities that reach the seas, oceans, bays will be under water or, in the worst case scenario, will be partially flooded, which will also be a huge human ecological and catastrophe in every sense.

3) The ozone layer (which is otherwise a non-renewable resource) will be so disturbed by the increasing pollution of planet Earth that the infrared-red rays of the Sun will be so strong that many animal and plant species will disappear forever.

4) The temperature on Earth will in the next 300 - 350 years. rise so much that water from the sea, and the oceans, lakes will start to evaporate irreversibly at high speed because of the effects of climate change, Earth's gravity will begin to weaken, firstly, climate change which will then have a huge negative impact on the entire planet and secondly, the Earth's gravity will weaken due to the in creasing number of volcanoes that will activate in the future, the increasing number of earthquakes, the increasing number of tsunamis.

5) Skin cancer in humans, due to the enormously high temperatures then, will become more prevalent in humans. In general, people will begin to die massively on earth in the next (400 - 450) years. Not only skin cancer, people will die from an increasing number of psychiatric and nervous diseases, because infrared radiation from the sun is very unhealthy for the human population.

6) In the coming centuries, there will be increasing reproduction of harmful insects, and in general, a major invasion of rodents such as rats, mice, etc. The reptile gradation will be very strong.

7) As the decades and centuries go by, agricultural production will be diminishing (the production of wheat, corn, and other strategic crops), and it is the basis of human survival on planet Earth. Agricultural production and consequently the production of animal feed will be diminished, not because they will have no one to cultivate the land, but because the climate will be so disturbed that they will not succeed in producing crops. There will be heavy rainfall somewhere, there will be heavy droughts, which is still happening today.

8) In the next 500 - 550, because of the even higher temperatures on Earth, a large quantity of water from the Earth's surface will evaporate so irreversibly that planet Earth will begin to lose its weight, which will formally be the end of life on Earth, because life without water is unthinkable.

9) When the gravity of the Earth is so weak, the part of atmosphere will transfer into space, due to the increasing loss of Earth's weight, the Earth's axis will be corrected, there will be a disturbance of the Earth's magnetic field, the cessation of seasons and the formal end of life on Earth.

10) Planet Earth would eventually become one flamboyant smaller planet without life, and only some species of insect would survive this cataclysm of Earth mentioned in points 1 to 9 . Earth would be similar to Mars only slightly 
larger, because Earth is otherwise larger than Mars.

\section{Important Explanation}

The Climate Change Committee (Faith, 2003), proposes that 30,000 acres of forest area be planted annually, more than twice the size of new trees planted last year.

It was also said that this would likely have to be increased to 50,000 hectares unless other carbon reduction targets were achieved.

The British government said it was planning to "rapidly expand the forest cover".

It has committed to the (Faith, 2003), is the goal of reducing all greenhouse gas emissions by 2050 - the so-called total zero.

The committee-made up of experts in science, economics and businesssaid it requires that afforested areas be increased from 13 percent of UK land to 17 percent.

The Woodland Trust charity said it would be the equivalent of about 1.5 billion new trees and that future generations would be "betrayed" by poorer air quality and increased "urban heat" if the board's goals were not met (Faith, 2003).

The (Faith, 2003), said 30,000 acres of new tree trunks are needed annually by 2050.

That's the equivalent of covering more than 46,000 standard football stadiums or spaces of about three-quarters the size of White Island each year.

Eva Kmietovic, team leader of the Committee on Transport and Agriculture, said: "The government must develop a strategy to reach the 30,000-acre target, and that must happen quickly".

However, the (Faith, 2003), said tree planting may need to be further increased to 50,000 hectares a year and more than three times the amount of forested area planted in 2018-2019, if other sectors of the economy, including industry and transport, do not sufficiently reduce emissions.

Kmietovic added: "It takes time for the trees to grow and absorb carbon. It has a lot of upfront costs when planting trees".

"The government must involve farmers in all this".

The (Faith, 2003), said it had not worked out what the point was when tree planting had to be raised to 50,000 acres a year, but "it will depend on everything that's going on in the economy".

WHAT TO DO NOW IN ALL COUNTRIES. If one country fails everything goes down. (When I say state I mean states that have recognized the UN. I don't mean non-autonomous territories-sharp in the Pacific):

According to official records, there are 194 countries in the world. PROPOSED MEASURES:

1) That each country, but EVERYONE, urgently adopts an URGENT EMERGENCY GAS REDUCTION PROGRAM, "EACH COUNTRY FOR ITSELF, to reduce the GHG emissions by at least 33\%... IMIDIATLY".

2) That every state begins afforestation on large areas (PinusNigraLat). Pi- 
nusNigra Lat. can thrive at all altitudes and in all lands. These future PinusNigra pine forests will be young forests for 15 - 20 years, which can take on an ecological function. Black pine is resistant to all pollution, fast growing, and can absorb harmful gases. The more black pine forests in the world, the less pollution there is. Black pine has low land requirements while improving soil as a pioneer species. Further into adulthood, these forests also have an economic effect.

3) (PinusNigra Lat.) Is the only species of conifers and wood in general that can grow relatively quickly, that during growth it is very resistant-immune, to all the harmful effects that come from polluting the planet, while being very modest when it comes to soil (only the sea that young seedlings are nurtured until they start to stand alone), and 15 - 20 years to 25 years (relatively short) period, and it would mean a lot to planet Earth if black pine were to be planted all over planet Earth). It will already have great ecological valence and function in the adsorption of harmful substances from the air so that to some extent planet Earth would be saved (Tokar \& Krekulova, 2005).

4) That the UN Special Commission on Inspection controls every state as much as possible because of the large number of states. To control the implementation of points 1 and 2. That state which would not adhere to that signed agreement would have: THE MOST ECONOMIC SANCTIONS NOT RECORDED IN ITS HISTORY. THE SANCTIONS WOULD BE ENFORCED UNTIL THE REVISION IS NOT CONSIDERED THAT IT HAS BEEN ADMITTED TO CONTRACT THE SIGNED AGREEMENT.

If nothing is done, against: climate change, the emission of harmful gases into the atmosphere, the destruction of forests, pollution of the environment-riverslakes-seas-life on planet Earth will not be possible. PLANET Earth will be a lifeless planet (Figures 6-9). Earth will transform after centuries of stone, a lifeless planet.

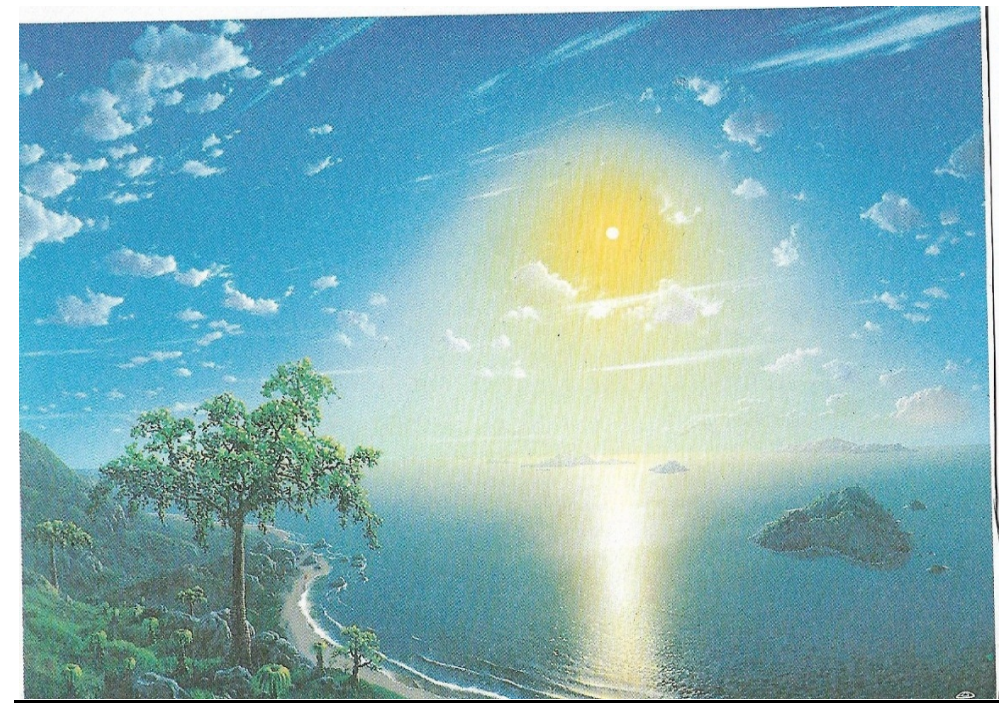

Figure 6. After 500 to 600 years, the last ordinary day on planet Earth has dawned. (Note: source: https://www.google.com/climatechange). 


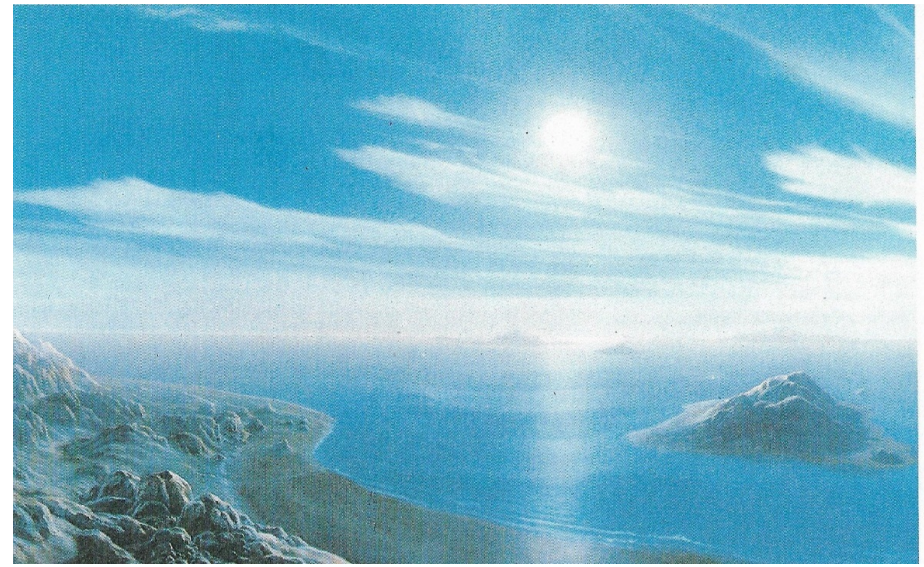

Figure 7. Planet Earth will heat up so much, many life forms will be destroyed, and the sea and ocean coastline will recede. (Note: source: https://www.google.com/climatechange).

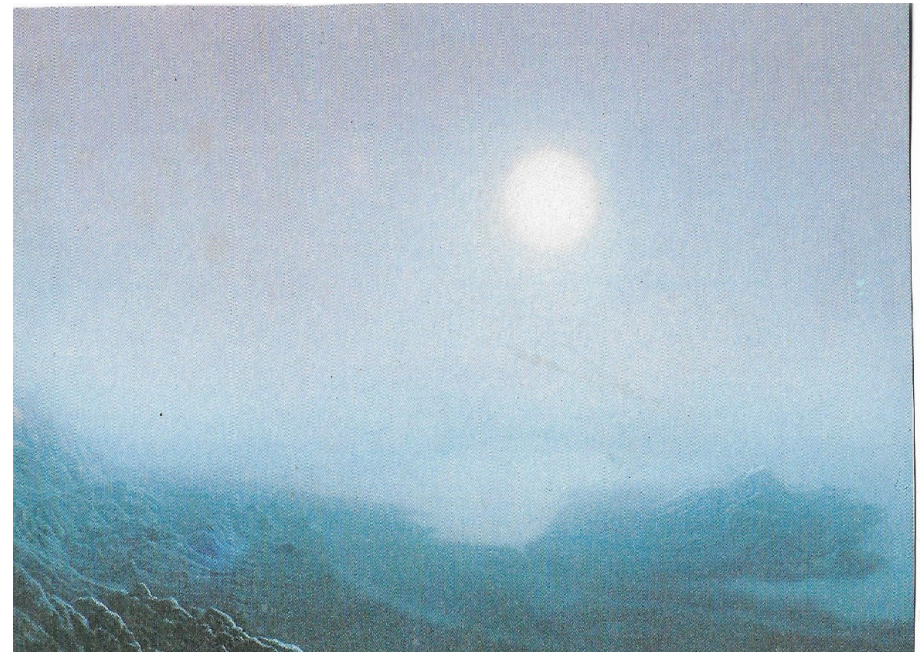

Figure 8. The oceans and the sea will evaporate quickly and the atmosphere will go into space due to the increasing weakening of Earth's gravity. (Note: source: https://www.google.com/climatechange).

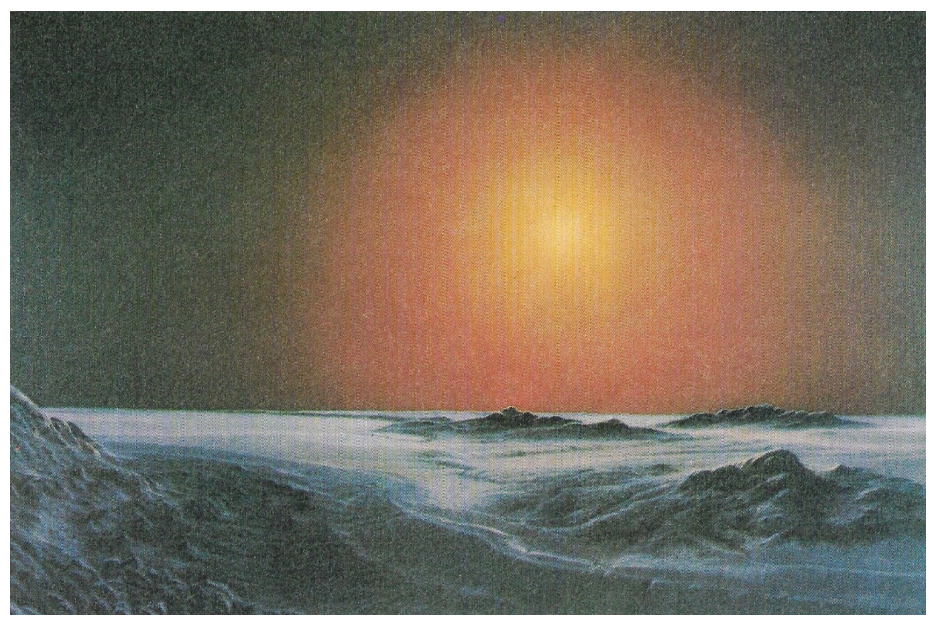

Figure 9. It will turn the earth into a dry, stripped airless world. (Note: source: https://www.google.com/climatechange). 


\section{Conclusion}

The world is probably in the midst of the hottest ten years since temperature records began to be recorded in 1850, scientists say.

The Met Office predicts that temperatures in the next five years are likely to be higher than pre-industrial levels.

In the next five years, there is also a chance that we will face a year in which the rise in average global temperature could be greater than 1.5 degrees.

A degree and a half are considered a critical threshold for climate change.

If the data match the forecasts, the decade from 2014 to 2023 will be the warmest in more than 150 recent years.

They concluded that a massive carbon reduction effort would be needed to prevent the world from crossing that border by 2030. New analysis shows that the chances of this happening in the next five years are ten percent higher.

"This is the first time that forecasts have shown a high risk of overspending and this is only temporary. We are talking about individual years that exceed the 1.5-degree level", said Prof. Skyf.

"But the fact that in the next few years this could be due to a combination of global warming and fluctuations over events like El Nino, does not mean that we are approaching it".

That July 29, 2019, the population consumed more natural resources than the planet will produce this year.

Known as the Ecological Debt Day, this event was the earliest since it began to be celebrated in the 1970s.

"Ecological debt day is calculated on the basis of how much water, forests, metals and other resources are available on the planet and how quickly they are consumed", Professor Ante Vujic of the Department of Biology and Ecology at the Faculty of Science in Novi told the BBC.

"If we take all of the resources as a principal available to us within one year, when we exceed it, environmental debt is created".

So as of today, the world's population is using resources that the planet will only be able to produce in the coming year.

The Global Ecological Footprint Network calculates which day a population becomes eco-friendly.

That network calculated that humanity currently uses nature 1.75 times faster than the planet's ecosystem can regenerate.

This means that we need 1.75 Earth to be at zero.

"We have not inherited the planet and the resources we spend on it from our ancestors, but borrowed it from our generations".

\section{Conflicts of Interest}

The author declares no conflicts of interest regarding the publication of this paper. 


\section{References}

Ault, T. R., \& George, S. S. (2010). The Mangitude of Decadal and Multidecadal Variability in North American Precipitation. Journal of Climate, 23, 842-850. https://doi.org/10.1175/2009JCLI3013.1

Barnett, T. P., Adam, J. C., \& Lettenmaier, D. P. (2005). Potential Impacts of a Warming Climate on Water Availability in Snow-Dominated Regions. Nature, 438, 303-309. https://doi.org/10.1038/nature04141

Biondi, F., \& Waikul, K. (2002). DENDROCLIM2002: A C++ Program for Statistical Calibration of Climate Signals in Tree-Ring Chronologies. Computers \& Geosciences, 30, 303-311. https://doi.org/10.1016/j.cageo.2003.11.004

Bradley, R. S., Hughes, M. H., \& Mann, M. E. (2000). Comments on Detection and Attribution of Recent Climate Change: A Status Report. Bulletin of the American Meteorological Society, 81, 115-118. https://doi.org/10.1175/1520-0477(2000)081<2987:CAACOD>2.3.CO;2

Briffa, K. R., Osborn, T. J., Schweingruber, F. H., Jones, P. D., Shiyatov, S. G., \& Vaganov, E. G. (2002). Tree-Ring Width and Density Data around the Northern Hemisphere: Part Local and Regional Climate Signals. The Holocene, 12, 737-757. https://doi.org/10.1191/0959683602hl587rp

Brković, D. (2015). Vascular Flora of the Highlands Areas of Northwestern Serbia and Sumadija, Ecological-Phytogeographic Study (pp. 45-50). Doctoral Dissertation, Belgrade.

Christian-Smith, J., Levy, M. C., \& Gleick, P. H. (2014). Maladaptation to Drought: A Case Report from California, USA. Sustainability Science, 10, 491-501.

Daly, C., Halbleib, M., Smith, J. I., Gibson, W. P., Doggett, M. K., Taylor, G. H., Curtis, J., \& Pasteris, P. P. (2008). Physiographically Sensitive Mapping of Climatological Temperature and Precipitation across the Conterminous United States. International Journal of Climatology, 28, 2031-2064. https://doi.org/10.1002/joc.1688

Eamus, D., \& Jarvis, P. G. (1989). The Direct Effects of Increase in the Global Atmospheric $\mathrm{CO}_{2}$ Concentration on Natural and Commercial Temperate Trees and Forests. Advanced in Ecological Research, 19, 21-45. https://doi.org/10.1016/S0065-2504(08)60156-7

Faith, D. P. (2003). Environmental Diversity (ED) as Surrogate Information for Species-Level Biodiversity. Ecography, 26, 374-379. https://doi.org/10.1034/j.1600-0587.2003.03300.x

Friedrich, M., Remmele, S., Kromer, B., Hofmann, J., Spurk, M., Kauser, K., Orcel, C., \& Kuppers, M. (2007). The 12,460-Year Hohenheim Oak and Pine Tree-Ring Chronology from Central Europe; A Unique Annual Record for Radiocarbon Calibration and $\mathrm{Pa}$ leoenvironment Reconstructions. Radiocarbon, 46, 1111-1122. https://doi.org/10.1017/S003382220003304X

Fritts, H. C. (1974). Relationships of Ring Widths in Arid-Site Conifers to Variations in Monthly Temperature and Precipitation. Ecological Monographs, 44, 411-440. https://doi.org/10.2307/1942448

Funk, C., Hoell, A., \& Stone, D. (2014). Examining the Contribution of the Observed Global Warming Trend to the California Droughts of 2012/13 and 2013/14. Bulletin of the American Meteorological Society, 95, S11-S15.

Grabner, M. (2005). Functional Tree Ring Analysis: Wood as an Information Source, to Understand, Physiological, Environmental and Technological Questions (pp. 77-83). Doctor Dissertation, Wien: Universitat für Bodenkultur.

Loomis, J., Koteen, J., \& Hurd, B. (2003). Economic and Institutional Strategies for 
Adapting to Water Resource Effects of Climate Change. In W. M. Lewis Jr. (Ed.), Water and Climate in the Western United States (pp. 235-249). Boulder, CO: University of Colorado Press.

Meffe, G. (2000). In Nature and Human Society: The Quest for a Sustainable World, National Research Council (NRC).

Sano, M., Furuta, F., \& Sweda, T. (2009). Tree-Ring-Width Chronology of Larix gmelinii as an Indicator of Changes in Early Summer Temperature in East-Central Kamchatka. Journal of Forest Research, 14, 147-154. https://doi.org/10.1007/s10310-009-0123-y

Tokar, F., \& Krekulova, E. (2005). Structure, Quality, Production, LAI, and Dendrochronology of 100 Years Old Austrian Pin (Pinus Nigra Arn) Stand. Journal of Forest Science, 51, 67-76. https://doi.org/10.17221/4545-JFS

Wilson, R. J. S., Luckman, B. H., \& Esper, J. (2005). A 500 Year Dendroclimatic Reconstruction of Spring-Summer Precipitation from the Lower Bavarian Forest Region, Germany. International Journal of Climatology, 25, 611-630.

https://doi.org/10.1002/joc. 1150

Williams, A. P., Allen, C. D., Macalady, A. K., Griffin, D., Woodhouse, C. A., Meko, D. M., Swetnam, T. W., Rauscher, S. A., Seager, R., Grissino-Mayer, H. D., Dean, J. S., Cook, E. R., Gangodagamage, C., Cai, M., \& McDowell, N. G. (2013). Temperature as a Potent Driver of Regional Forest Drought Stress and Tree Mortality. Nature Climate Change, 3, 292-297. https://doi.org/10.1038/nclimate1693

Wullschleger, S. D. et al. (1990) On the Potential for a $\mathrm{CO}_{2}$ Fertilization Effect on Forest Trees an Assessment of 58 Controlled Exposure Studies and Estimates on the Biotic Growth Factor. In G. M. Woodwell (Ed.), Biospheric Feedbacks in the Global Climate System: Will the Warming Speed the Warming (pp. 78-81). Oxford: Oxford University Press. 